\title{
Pnömoni Tanısı İle Hastaneye Yatırılan Çocuk Hastalarda Olası Risk Faktörlerinin Morbidite Üzerine Etkileri
}

\author{
Effects of Possible Risk Factors on Morbidity in Child Patients \\ Hospitalized With Pneumonia
}

\author{
Pınar SAKA ÜMiT'1 , Güzin CINEL²
}

\author{
${ }^{1}$ Ankara Şehir Hastanesi, Çocuk Hastanesi, Çocuk Sağlığı ve Hastalıkları Kliniği, Ankara, Türkiye \\ ${ }^{2}$ Ankara Şehir Hastanesi, Çocuk Hastanesi, Çocuk Sağlığı Göğüs Hastalıkları Kliniği, Ankara, Türkiye
}

\begin{abstract}
ÖZ
Amaç: Çocukluk çağı pnömonileri, özellikle gelișmekte olan ülkelerde en önemli mortalite ve morbidite nedenidir. Bu çalısmada pnömoni tanısı ile hastaneye yatışı yapılan çocukların demografik özellikleri ve pnömoni gelişiminde önemli risk faktörleri incelenmiş; komplikasyon gelişimi ve prognoz üzerine etkilerinin değerlendirilmesi amaçlanmıştır.

Gereç ve Yöntemler: Bu tek merkezli retrospektif kesitsel çalışmada, Pediatri Servisleri ve Yoğun Bakım Ünitesi (YBÜ) 'ne Ocak 2017- Ocak 2018 tarihleri arasında pnömoni tanısı ile yatıılan hastalar değerlendirildi. Hastaların demografik bulguları, anne sütü alım öyküsü, malnütrisyon varlığı, așılama durumu, kronik hastalık varlığı, kalabalık yașam koșulları, pasif sigara içiciliği gibi faktörlerin hastane yatışını ve yatış süresini ne kadar etkilediği, hastalık sonrasında komplikasyon gelişme durumu ve sağkalım bulguları incelendi.

Bulgular: Pnömoni tanısı ile yatıılan 289 hastanın \%53.3'ü kız olup ortanca yașları 14 aydı ve hastaların \%65.4'ü 2 yaşından küçüktü. Hastaların \%19.7'sinde prematüre doğum öyküsü olup \%76.1'i >2500 gr doğum ağırlığına sahipti; \%15.9'unun postnatal dönemde küvöz bakımı, \%6.2'sinin mekanik ventilatör intiyacı olmuştu. Hastaların \%31.5'inin hiç anne sütü almadığı, \%10'unun malnütre olduğu, \%18'inin rutin aşılarının eksik olduğu, \%26.6'sında pasif sigara maruziyeti, \%37'sinde kronik hastalık varlığı saptandı. Bașvuruda en sık gözlenen semptomlar öksürük (\%86.5) ve ateș (\%60) olup ortanca semptom süresi 3 gün idi. Başvuruda en sık saptanan fizik muayene bulguları ise takipne (\%68.9) ve retraksiyonlar (\%60.9)'di. Radyolojik incelemelerinde \%85.8'inde pnömonik infiltrasyon, \%3.5'inde lober konsolidasyon, \%2.8'inde pnömonik infiltrasyon+plevral effüzyon, \%2.1'inde pnömonik infiltrasyon+atelektazi, \%1.1'inde lober konsolidasyon+plevral effüzyon ve \%0.3'ünde atelektazi saptandı. Hastanede yatıșları süresince hastalardan alınan kültürlerin \%9'unda mikroorganizma üredi. Hastaların \%56,7'si tekli antibiyotik tedavisi, diğerleri kombine antibiyotik tedavileri aldılar. Hastaneye yatıș süresi ortanca 9 gün (1-115 gün) olup izlemde hastaların \%25.6'sının yoğun bakım ünitesi izlemi gerekti. Pnömoni seyrinde komplikasyon gelişen hasta oranı \%13.1 olarak saptandı. Yaş, prematüre doğum öyküsü, düşük doğum ağırlı̆̆ı, postnatal dönemde küvözde veya mekanik ventilatörde kalma, malnütrisyon varlı̆̆ı, kronik hastalık varlığı, başvuru muayenelerinde takipne, retraksiyon, ateş, ral-ronküs varlığı, akciğer grafisinde plevral effüzyonla birlikte pnömonik infiltrasyon veya lober konsolidasyon varlığı parametreleri uzamış hastane yatışında, pnömoni seyrinde komplikasyon gelişmesinde, YBÜ yatış gereksiniminde olası risk faktörleri olarak saptandı.
\end{abstract}

Sonuç: Küçük yaş, prematüre doğum öyküsü, düşük doğum ağılığı, anne sütü almamak, eksik aşılanma ve malnütrisyon çocuklarda pnömoni nedenli hastaneye yatışlar için önemli risk faktörleridir. Yoğun bakım ünitesine yatış gereksinimini,

(1)

SAKA ÜMіT P : 0000-0002-3871-6675 CINEL G : 0000-0002-6209-196X
Çıkar Çatıșması / Conflict of Interest: Tüm yazarlar adına, sorumlu yazar çıkar çatıșması olmadığını belirtir.

Etik Kurul Onayı / Ethics Committee Approval: Bu çalşmada ulusal ve uluslararası etik kurallara uyulmuştur. Bu çalışma için Ankara Şehir Hastanesi Klinik Araştırmalar Etik Kurulu'ndan 03.10.2019 tarih ve E1/078/2019 karar numarası ile onay alınmıştır. Kayıt sırasında veliler tarafindan araştırmaya katılım için bilgilendirilmiș bir onay imzalanmıștır.

Yazarların katkısı / Contribution of the Authors: SAKA ÜMiT P: Araştırma ve/veya makalenin hipotezini veya fikrini oluşturan, Sonuçlara ulașmak için planlama/ metodoloji belirleme, Araștırma/çalıșmanın sorumluluğunu üstlenmek, ilerlemenin seyrini denetlemek, Hasta takibinde sorumluluk almak, ilgili biyolojik malzemelerin toplanması, veri yönetimi ve raporlama, deneylerin yürütülmesi, Sonuçların mantıksal olarak Yorumlanması ve sonuçlandırılması, Çalışma için gerekli literatür taramasında sorumluluk almak, Çalıșmanın bütününün veya önemli bölümlerinin yazımında sorumluluk almak, Yazım ve dilbilgisi dıșında bilimsel olarak gönderilmeden önce makaleyi gözden geçirme, CiNEL G: Araștırma ve/veya makalenin hipotezini veya fikrini olușturan, Sonuçlara ulașmak için planlama/metodoloji belirleme, Araștırma/çalışmanın sorumluluğunu üstlenmek, ilerlemenin seyrini denetlemek, Hasta takibinde sorumluluk almak, ilgili biyoloijk malzemelerin toplanması, veri almak, Çalışmanın bütününün veya önemli bölümlerinin yazımında sorumluluk almak, Yazım ve dilbilgisi dışında bilimsel olarak gönderilmeden önce makaleyi gözden geçirme

Atıf yazım şekli / How to cite : Saka Ümit P ve Cinel G. Pnömoni Tanısı lle Hastaneye Yatırlan Çocuk Hastalarda Olası Risk Faktörlerinin Morbidite Üzerine Etkileri. Türkiye Çocuk Hast Derg 2021;15:262-271.
Yazıșma Adresi / Correspondence Address:

Pınar ÜMiT SAKA

Ankara Șehir Hastanesi, Çocuk Hastanesi, Çocuk Sağliğı ve Hastallıları Kliniği, Ankara, Türkiye

E-posta: drpinarsaka@gmail.com
Geliş tarihi / Received : 02.03.2020 Kabul tarihi / Accepted : 18.06.2020 Elektronik yayın tarihi : :28.09.2020 Online published

DOI: 10.12956/tchd.688129 
yoğun bakım ünitesinde yatış süresini ve komplikasyon gelişimini etkileyen faktörler ise ek nörolojik ve genetik hastalıkların varlığı ve düșük oksijen saturasyonu olarak belirlenmiştir. Hastalığın seyrini ve prognozunu, komplikasyonlarını ve hastanın hastanede yatış süresini etkileyen olası risk faktörlerinin belirlenip önlenmesi çocukluk çağında pnömonilerin morbiditesini azaltacaktır.

Anahtar Sözcükler: Komplikasyon, Pnömoni, Risk faktörleri

\section{ABSTRACT}

Objective: Childhood pneumonias are the most important mortality and morbidity reasons especially in developing countries. In this study, demographic attributes and important risk factors among children hospitalized with pneumonia were examined; their effects on complications and prognosis were evaluated.

Material and Methods: In this retrospective cross-sectional study, children diagnosed with pneumonia and hospitalized between January 2017- January 2018 in Pediatric Services and Intensive Care Unit (ICU) were evaluated. How factors such as demographic findings, nutrition (breast milk), presence of malnutrition, vaccination history, presence of chronic disease, crowded living conditions, passive smoking affected hospitalization and its duration; development of complications after the disease and survival findings were examined.

Results: Among 289 hospitalized patients, 53.3\% were female, median age was 14 months and 65.4\% of the patients were under 2 years old. Nineteen point seven percent of the patients had premature birth history, $76.1 \%$ of them had $>2500$ gr birth weight. It was determined from the postnatal histories that $15.9 \%$ of them required incubator care, $6.2 \%$ of them required mechanical ventilator. Among the patients, it was found out that $31.5 \%$ of the patients did not receive breast milk, $10 \%$ had malnutrition, $18 \%$ had incomplete vaccination, $26.6 \%$ were exposed to passive smoking, $37 \%$ had a chronic disease. The most common symptoms observed during the admission were cough (86.5\%) and fever (60\%), median symptom period was 3 days. The most common physical examination findings detected were tachypnea (68.9\%) and retractions (60.9\%). In their radiological evaluations, it is detected that $85.8 \%$ of the patients had pneumonic infiltration, 3,5\% had lobar consolidation, $2.8 \%$ had pneumonic infiltration+pleural effusion, $2.1 \%$ had pneumonic infiltration+atelectasis, $1.1 \%$ had lober consolidation+pleural effusion and $0.3 \%$ had atelectasis. During their stay in the hospital, microorganisms could be detected in $9 \%$ of the culture samples taken from the patients. Fifty six point sevent percent of the patients received mono antibiotic therapy while the rest of them received combined antibiotic therapy. Median hospitalization period was 9 days (1-115 days) and $25.6 \%$ of the patients required ICU monitoring. Complication development rate of the patients in the course of pneumonia detected as $13.1 \%$. Age, premature birth history, low birth weight, staying in the incubator or in mechanical ventilator during the postnatal period, presence of malnutrition, presence of chronic disease, tachypnea, retraction, fever, rale-ronchus parameters during physical examinations at the admission, presence of pneumonic infiltration or lobar consolidation with pleural effusion on the chest x-ray, were determined as the parameters affecting prolonged hospitalization, complication development in the follow-up and in ICU stay.

Conclusion: Being under 2 years of age, prematurity, low birth weight, absence of breast milk, incomplete vaccination and malnutrition are the significant risk factors for pneumonia dependent hospitalizations among children. Presence of additional neurological and genetic diseases and low oxygen saturation are identified as the factors impacting the need to stay in intensive care unit, length of stay and complications. Identifying and preventing the risk factors affecting course of the disease and the prognosis, its complications and hospitalization period will reduce the morbidity of the pneumonias in childhood.

Key Words: Complication, Pneumonia, Risk factors

\section{GiRiş}

Çocuklarda hastane başvurularının en sık nedeni solunum yolu enfeksiyonlarıdır. Bu hastalıkların içinde pnömoni, dünya çapında çocuklarda önemli bir mortalite ve morbidite nedenidir. Dünya genelinde her yıl yaklaşık 120 milyondan fazla çocuk pnömoni tanısı almakta ve 1,3 milyon civarında ölümle sonuçlanmaktadır. Gelişmekte olan ülkelerde 2 yaşın altındaki pediatrik ölümlerin yaklaşık \%80’i pnömoni nedenlidir (1). Dünya Sağlık Örgütü'nün 2017 yllı raporuna göre, 5 yaş altı çocuklarda tüm ölümlerin \%15'i pnömoni nedenli olduğu bildirilmiştir (2).

Hastaneye yatış gerektiren pnömoniler, ağır ve çok ağır pnömonilerdir ve pediatrik yaş grubu hastalarda önemli bir mortalite ve morbidite sebebidir. Risk faktörleri arasında konağın risk faktörleri, düşük sosyoekonomik düzey, hava kirliliğine maruz kalmak, pasif sigara içiciliği, aşılarının eksik olması ve sağlık koşullarının uygun olmadığı kalabalık ortamlarda konaklama, beslenme imkanlarının yetersizliği, kötü hijyen koşulları, yaşama alanlarında alt yapı yetersizliği sayılabilir.
Solunum yolu problemleri ile hastaneye başvuran hastaların risk faktörleri değerlendirilebilir; morbidite ile ilişkili olarak yatış süresi ve gelişen komplikasyonlar karşılaştırılabilir; bağışıklama ve yaşam koşullarının düzenlenmesi ile önlenebilecek hastalıklar hakkında bilgi sahibi olunabilir.

Bu çalışmada pnömoni tanısı ile hastaneye yatışı yapılan çocukların demografik özellikleri ve pnömoni gelişiminde önemli risk faktörleri incelenmiş; komplikasyon gelişimi ve prognoz üzerine etkilerinin değerlendirilmesi amaçlanmıştır.

\section{GEREÇ ve YÖNTEMLER}

Bu tek merkezli retrospektif kesitsel çalışmada, Pediatri Servisleri ve Yoğun Bakım Ünitesi'ne Ocak 2017- Ocak 2018 tarihleri arasında pnömoni tanısı ile yatıılan hastalar değerlendirildi.

Çalışmaya dâhil edilme kriterleri: Dünya Sağlık Örgütü'nün belirlediği pnömoni kriterlerine göre (Ateș ve/veya akut solunumsal belirtilerle birlikte akciğer grafisinde parankimal 
tutulum eşlik etmesi; öykü ve fizik muayene bulguları ile desteklenmesi) toplum kaynaklı pnömoni tanısı ile Ocak 2017 - Ocak 2018 arasında hastaneye yatırılmış hastalar çalışmaya dahil edildi.

Çalışma dışı bırakılma kriterleri: Hastane kaynaklı ve ventilatör ilişkili pnömoniler, pnömoni dişındaki alt solunum yolu enfeksiyonları, ayaktan izlenen hastalar, yenidoğan döneminde yatırılan ve takip edilen hastalar, immünsüprese, evde ventilatör desteği gören ve kronik akciğer hastalığı olan hastalar çalışma dışı bırakıldı.

Araştırılması planlanan veriler için bir veri formu oluşturuldu. Buna göre; hastanın yaşı, kronik hastalık varlığı, anne baba arasında akrabalık durumu, anne yaşı, sosyodemografik özellikleri, beslenme imkanları (anne sütü alımı), malnütrisyon varlığı, kalabalık yaşam koşulları, pasif sigara içiciliği, aşılama durumu gibi faktörlerin hastane yatışını ve yatış süresini ne kadar etkilediği, üreyen mikroorganizmaların neler olduğu, hastalık sonrasında komplikasyon gelişme durumu ve sağkalım bulguları incelendi. Malnütrisyon varlığı, hastaların epikrizlerinden alınan fizik muayene bilgilerinde kilo veya boy Ölçümlerinin 3 persentil altında olması ile değerlendirildi. Doğum haftası 37 hafta ve altı olanlar prematüre doğum öyküsü olan grupta değerlendirildi. Çekirdek aile haricinde diğer akrabaları ile kalan çocukların hane özellikleri geniş aile olarak tanımlandı. Bu çalışma için Ankara Şehir Hastanesi, Klinik Araştırmalar Etik Kurulu'ndan 03.10.2019 tarih ve E1/078/2019 karar numarası ile onay alınmıştır.

İstatistiksel değerlendirme Statistical Package for Social Sciences for Windows 20 (IBM SPSS Inc., Chicago, IL) programı kullanılarak yapıldı. Verilerin normal dağılımı KolmogorovSmirnov testi ile değerlendirildi. Sayısal değişkenlerden normal dağılım gösterenler ortalama \pm standart sapma olarak, göstermeyenler median (en düşük değer- en yüksek değer) olarak gösterildi. Kategorik değişkenler sayı ve yüzde olarak belirtildi. Normal dağılım gösteren sayısal verilerin analizinde iki grup arasında kıyaslamalarda bağımsız örneklem t testi, üç grup arasındaki kıyaslamalarda ANOVA testi kullanıldı. Normal dağılım göstermeyen sayısal verilerin analizinde iki grup arasında kıyaslamalarda Mann-Whitney $U$ testi, üç grup arasındaki kıyaslamalarda Kruskall Wallis $\mathrm{H}$ testi kullanıldı. Kategorik verilerin analizinde Ki-kare testi ve Fisher'ın Kesin Ki-Kare testi kullanıldı. p<0,05 değeri anlamlı kabul edildi.

\section{BULGULAR}

Toplum kaynaklı pnömoni tanısı ile Ocak 2017- Ocak 2018 tarihleri arasında hastanede yatırılan toplam 320 hastanın 258'i Türk, 62'si Suriye uyrukluydu. 31 Suriyeli hastanın dil problemi nedeniyle bilgilerine ulaşılamadı. Araştırma için gerekli bilgilere ulaşılabilen 289 hasta çalışmaya dahil edildi. Hastaların \%53.3'ü kız, \%46.7'si erkekti, yaș aralığı 1 ay ile 17.5 yaş aralığında olup ortancası 14 ay olarak saptandı ve hastaların \%81'i 5 yaş altıydı.
Hastaların demografik özellikleri Tablo l'de özetlenmiştir.

Yatırıldığı gün alınan öykülerinde hastaların \%86.5'inde öksürük, \%60'ında ateş, \%25.3'ünde solunum sayısında artış vardı ve semptom süresi ortanca 3 gündü. Fizik muayene bulgularında hastaların \%68.9'unda takipne, \%60.9'unda retraksiyon, \%37.5'inde ateş, \%48.1'inde ral-ronküs, \%11.8'inde havalanma farkı saptandı. Hastaların \%10'unda malnütrisyon saptandı. Yatırıldığı gün yapılan laboratuvar tetkiklerinde, hastaların ortanca beyaz küre (BK) sayısı 11100 (I/ $\mathrm{mm}^{3)}$ ve ortanca CRP düzeyi 2 mg/l'di. (Tablo II)

Pnömonili çocuklarda altta yatan kronik hastalığı olanların oranı \%37'di. \%16.6'sı nörolojik hastalık öyküsü (serebral palsi, nörometabolik hastalıklar) olanlardı.

Hastanede yatışları süresince hastalardan alınan kültürlerin (kan, balgam, ETA, sürüntü kültürleri ve solunum yolu sekresyonlarından alınan viral panel) \%9'unda mikroorganizma gösterildi (Tablo III).

Hastaların \%56.7'si tekli antibiyotik tedavisi, \%40.5'i kombine antibiyotik tedavileri aldıar. Hastaların \%50.5'ine SAM (Sulbaktam/Ampisilin), \%24.2'sine klaritromisin, \%20 .1 'ine seftriakson verildiği saptandı. Antibiyotik tedavilerinin dağılımı Tablo IV'de gösterildi. 8 hastaya (\%2.8) viral pnömoni düşünülerek antibiyotik tedavisi başlanmadı.

Hastaneye yatış süresi ortanca 9 gün (1-115 gün) olup izlemde hastaların \%25.6'sının yoğun bakım ünitesinde izlemi gerekti. Pnömoni seyrinde komplikasyon gelişen hasta oranı \%13.1 olarak saptandı. Hastanemizde yatırılan hastaların büyük çoğunluğunun (\%75.1) maske ile O2 desteği aldığı görüldü.

Hastaların hastanede yatış süreleri bir hafta (ortanca 5 gün), iki hafta (ortanca 9 gün), iki hafta üzeri (ortanca 22 gün) olarak ayrıldı. İki hafta üzerinde hastane yatışı olan hastalarda ortanca yaş, prematüre doğum öyküsü olanların oranı ve malnütrisyon oranı bir hafta ile iki hafta arasında hastane yatışı olanlara kıyasla yüksek saptandı. Bir hafta ile iki hafta hastane yatışı olanlarda ortanca yaş farklılık göstermedi. İki hafta üzerinde hastane yatışı olan ile iki hafta hastanede yatışı olanlarda, özgeçmiş bilgilerinde postnatal dönemde küvözde kalma oranı benzer olup bir hafta hastanede yatışı olanlara kıyasla yüksek saptandı. İki hafta üzerinde hastane yatışı olan hastalarda kronik hastalık oranı, nörolojik hastalık oranı ve genetik hastalık oranı 1 hafta ile 2 hafta hastane yatışı olanlara kıyasla yüksek saptandı. İki hafta üzerinde hastane yatışı olanlarda mikroorganizma üremesi olanların oranı bir hafta hastane yatışı olanlara kıyasla yüksek saptandı. İki hafta üzerinde hastane yatışı olan hastalarda YBÜ yatış oranı ve ortanca yatış süresi, pnömoni seyrinde komplikayon oranı, Nazal CPAP ve mekanik ventilasyon solunum desteği alanların oranı, exitus olanların oranı bir hafta ile iki hafta hastane yatışı olanlara kıyasla yüksek saptandı. İki hafta hastane yatışı olanlarda YBÜ yatış oranı, pnömoni seyrinde komplikayon oranı, mekanik ventilasyon solunum desteği alanların oranı ve 
Tablo I: Hastaların demografik özellikleri.

\begin{tabular}{|c|c|c|c|c|}
\hline & & & & \\
\hline & Tüm popülasyon $n=289$ & $\begin{array}{c}\text { Türkiye } \\
\mathrm{n}=258\end{array}$ & $\begin{array}{c}\text { Suriye } \\
\mathrm{n}=31\end{array}$ & p \\
\hline $\begin{array}{l}\text { Cinsiyet } \\
\text { KIz } \\
\text { Erkek }\end{array}$ & $\begin{array}{l}154(53.3) \\
135(46.7)\end{array}$ & $\begin{array}{l}135(52.3) \\
123(47.7)\end{array}$ & $\begin{array}{l}19(61.3) \\
12(38.7)\end{array}$ & 0.450 \\
\hline $\begin{array}{l}\text { Yaş (yıl) } \\
1 \text { yaş } \\
1-2 \text { yaş } \\
2-3 \text { yaş } \\
3-5 \text { yaş } \\
5-10 \text { yaş } \\
10 \text { yaş ve üzeri }\end{array}$ & $\begin{array}{c}14(1-209) \\
137(47.4) \\
52(18.0) \\
23(8.0) \\
22(7.6) \\
27(9.3) \\
28(9.7)\end{array}$ & $\begin{array}{c}14.5(1-209) \\
113(43.8) \\
49(19.0) \\
21(8.1) \\
21(8.1) \\
26(10.1) \\
28(10.9)\end{array}$ & $\begin{array}{c}6(1-84) \\
24(77.4) \\
3(9.7) \\
2(6.5) \\
1(3.2) \\
1(3.2) \\
-\end{array}$ & $<0.001^{*}$ \\
\hline $\begin{array}{l}\text { Prenatal özellik } \\
\text { Yok } \\
\text { Sigara kullanımı } \\
\text { Diğer }\end{array}$ & $\begin{array}{l}254(87.9) \\
25(8.7) \\
10(3.5)\end{array}$ & $\begin{array}{l}227(88.0) \\
23(8.9) \\
8(3.1)\end{array}$ & $\begin{array}{l}27(87.1) \\
2(6.5) \\
2(6.5)\end{array}$ & 0.511 \\
\hline $\begin{array}{l}\text { Doğum haftası } \\
37 \text { hafta üstü } \\
37 \text { hafta ve altı }\end{array}$ & $\begin{array}{c}232(80.3) \\
57(19.7)\end{array}$ & $\begin{array}{c}203(78.7) \\
55(21.3)\end{array}$ & $\begin{array}{c}29(93.5) \\
2(6.5)\end{array}$ & 0.056 \\
\hline $\begin{array}{l}\text { Doğum şekli } \\
\text { NSVY } \\
\text { C/S }\end{array}$ & $\begin{array}{l}165(57.1) \\
124(42.9)\end{array}$ & $\begin{array}{l}139(53.9) \\
119(46.1)\end{array}$ & $\begin{array}{c}26(83.9) \\
5(16.1)\end{array}$ & $0.002^{*}$ \\
\hline $\begin{array}{l}\text { Doğum ağırlığı } \\
<1500 \mathrm{gr} \\
1500-2500 \mathrm{gr} \\
>2500 \mathrm{gr}\end{array}$ & $\begin{array}{c}- \\
69(23.9) \\
220(76.1)\end{array}$ & $\begin{array}{c}- \\
\text { 60(23.3) } \\
198(76.7)\end{array}$ & $\begin{array}{c}- \\
9(29.0) \\
22(71.0)\end{array}$ & 0.505 \\
\hline $\begin{array}{l}\text { Postnatal özellik } \\
\text { Yok } \\
\text { Küvözde kalma } \\
\text { Mekanik vantilatörde kalma }\end{array}$ & $\begin{array}{c}225(77.9) \\
46(15.9) \\
18(6.2)\end{array}$ & $\begin{array}{c}200(77.5) \\
43(16.7) \\
15(5.8)\end{array}$ & $\begin{array}{c}25(80.6) \\
3(9.7) \\
3(9.7)\end{array}$ & 0.425 \\
\hline $\begin{array}{l}\text { Anne sütü alımı } \\
\text { Yok } \\
\text { Var }\end{array}$ & $\begin{array}{c}91(31.5) \\
198(68.5)\end{array}$ & $\begin{array}{c}72(27.9) \\
186(72.1)\end{array}$ & $\begin{array}{l}19(61.3) \\
12(38.7)\end{array}$ & $<0.001^{*}$ \\
\hline $\begin{array}{l}\text { Aşı } \\
\text { Yok } \\
\text { Var }\end{array}$ & $\begin{array}{c}52(18.0) \\
237(82.0)\end{array}$ & $\begin{array}{c}34(13.2) \\
224(86.8)\end{array}$ & $\begin{array}{l}18(58.1) \\
13(41.9)\end{array}$ & $<0.001^{*}$ \\
\hline $\begin{array}{l}\text { Pasif sigara maruziyeti } \\
\text { Yok } \\
\text { Var }\end{array}$ & $\begin{array}{c}212(73.4) \\
77(26.6)\end{array}$ & $\begin{array}{c}186(72.1) \\
72(27.9)\end{array}$ & $\begin{array}{c}26(83.9) \\
5(16.1)\end{array}$ & 0.200 \\
\hline $\begin{array}{l}\text { Akrabalık } \\
\text { Yok } \\
\text { Var }\end{array}$ & $\begin{array}{c}211(73.0) \\
78(27.0)\end{array}$ & $\begin{array}{c}192(74.4) \\
66(25.6)\end{array}$ & $\begin{array}{l}19(61.3) \\
12(38.7)\end{array}$ & 0.135 \\
\hline $\begin{array}{l}\text { Malnütrisyon } \\
\text { Yok } \\
\text { Var }\end{array}$ & $\begin{array}{c}260(90.0) \\
29(10.0)\end{array}$ & $\begin{array}{c}232(89.9) \\
26(10.1)\end{array}$ & $\begin{array}{c}28(90.3) \\
3(9.7)\end{array}$ & 0.999 \\
\hline
\end{tabular}

exitus olanların oranı bir hafta hastane yatışı olanlara kıyasla yüksek saptandı ( Tablo V).

Mikroorganizma saptanan hastalarda saptanmayanlara kıyasla erkeklerin, prematüre doğum öyküsü olanların $(p<0.001)$, doğum ağırlığı 1500-2500 gr olanların ( $p=0.003)$, ebeveynleri arasında akrabalık eviliği olanların $(p=0.010)$, hastaların özgeçmişlerinden elde edilen bilgilere göre postnatal dönemde küvöz bakımı alanların ve mekanik vantilatörde kalanların $(p<0.001)$, malnütrisyon varlığı olanların oranı yüksek $(p=0.033)$, yenidoğan döneminde anne sütü alanların oranı düşük saptandı $(p=0.004)$. Mikroorganizma saptanan hastalarda saptanmayanlara kıyasla kronik hastalık oranı $(p=0.010)$, ve nörolojik hastalık oranı $(p=0.021)$ yüksek saptandı. Mikroorganizma saptanan hastalarda saptanmayanlara kıyasla yatış klinik bulgularından solunum sayısında artış olanların oranı $(p=0.016)$, ortanca CRP düzeyi $(p=0.048)$ ve ortanca yatış süresi yüksek saptandı $(p<0.001)$. Mikroorganizma saptanan hastalarda saptanmayanlara kıyasla YBÜ yatış oranı ( $p<0.001)$, pnömoni komplikasyon gelişenlerin oranı $(p<0.001)$, NCPAP desteği alanların oranı $(p=0.004)$, mekanik ventilasyon desteği 
Tablo II: Hastaların hastaneye yatırılıklarındaki semptom ve bulgular.

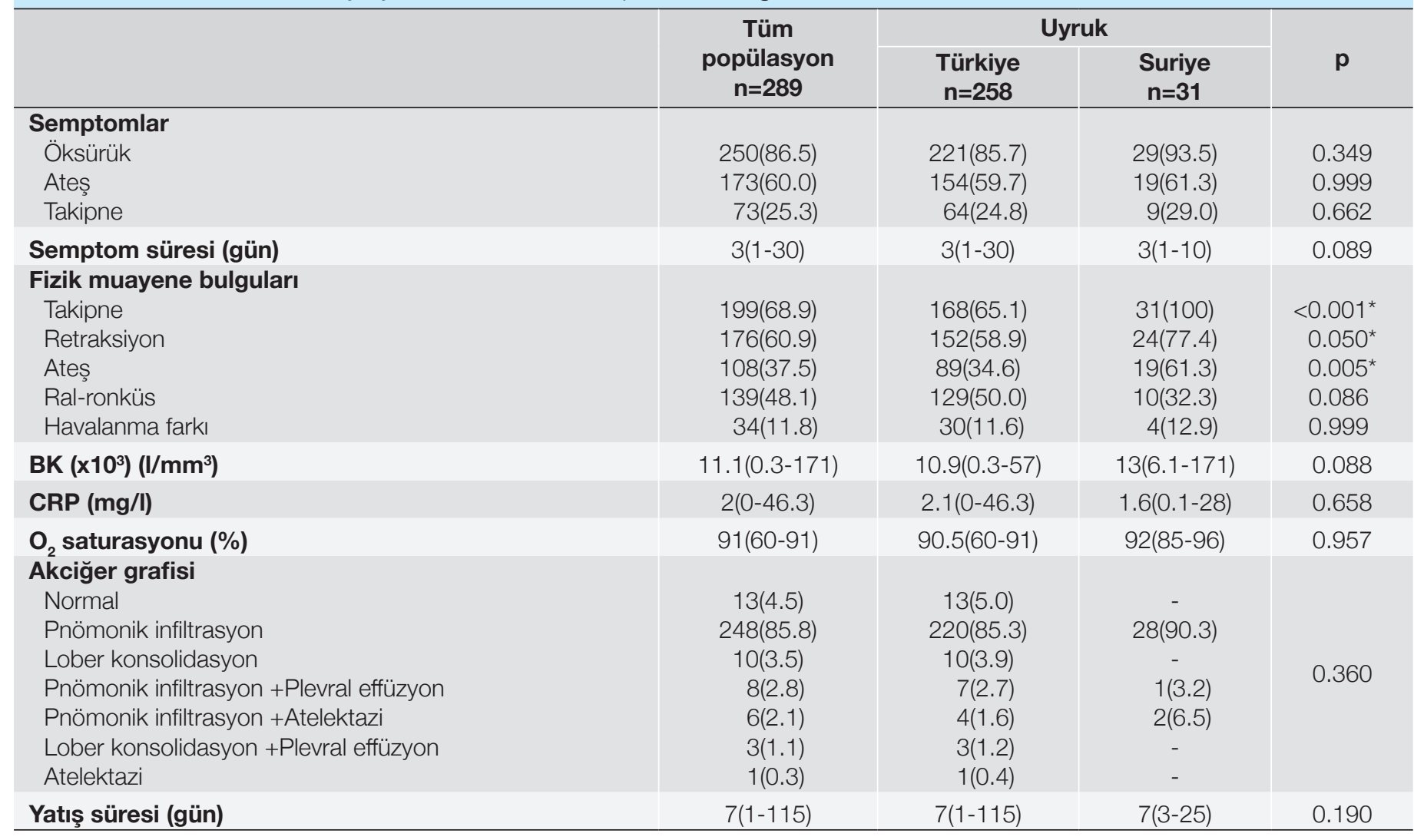

alanların oranı $(p<0.001)$ ve exitus olanların oranı yüksek saptandı $(p=0.001)$.

YBÜ ünitesine yatanlarda yatmayanlara kıyasla, hastaların özgeçmişlerinden elde edilen bilgilere göre postnatal dönemde küvözde kalanların oranı, mekanik vantilasyon alanların oranı ( $p=0.001$ ), malnütrisyon oranı yüksek saptandı $(p=0.006)$. YBÜ ünitesine yatanlarda yatmayanlara kıyasla kronik hastalığı olanların oranı $(p=0.001)$, nörolojik hastalığı olanların oranı $(p<0.001)$ ve genetik hastalığı olanların oranı yüksek saptandı $(p=0.030)$. YBÜ ünitesine yatanlarda yatmayanlara kıyasla yatış süresince izlemde mikroorganizma saptanan hastaların oranı yüksek saptandı ( $p<0.001)$; Candida albicans, Enterococcus, Pseudomonas (ETA), RSV, Influenza, Klebsiella pneumoniae, Coronavirüs, Staphylococcus aureus, Staphylococcus haemolyticus ve Staphylococcus epidermidis saptanan hastaların tamamının YBÜ ünitesine yatış yaptığı saptandı.

Komplikasyon gelişenlerde gelişmeyenlere kıyasla ortanca yaş yüksek saptandı $(p<0.001)$; diğer demografik özellikler anlamlı farklllık göstermedi. Komplikasyon gelişenlerde gelișmeyenlere kıyasla yatış klinik bulgulardan ateşi olan hastaların oranı ( $p=0.001$ ), solunum sayısı yüksek olan hastaların oranı ( $p=0.044)$, ortanca semptom süresi ( $p<0.001)$, fizik muayene bulgularından ateşi olan hastaların oranı $(p=0.001)$, havalanma farkı olan hastaların oranı ( $p=0.999)$, ortanca CRP düzeyi ( $(=0.002)$, lober konsolidasyonu olan hastaların oranı, pnömonik infiltrasyon ve atelaktezi birlikteliği olanların oranı, pnömonik infiltrasyon ve plevral effüzyon birlikteliği olanların oranı ve lober konsolidasyon ve plevral effüzyon birlikteliği olanların oranı yüksek saptandı $(p<0.001)$. Komplikasyon gelişenlerde gelişmeyenlere kıyasla seftriakson ( $p=0.003)$, seftazidim ( $p=0.009$ ), linezolid $(p=0.009)$, vankomisin $(p<0.001)$, meropenem $(p<0.001)$, klindamisin $(p<0.001)$, teikoplanin $(p<0.001)$ kullanım oranı yüksek saptandı. Komplikasyon gelişenlerde gelişmeyenlere kıyasla NCPAP $(p=0.006)$ ve mekanik ventilasyon desteği alanların $(p=0.017)$ ve exitus olanların oranı yüksek saptandı $(p=0.037)$.

\section{TARTIŞMA}

Bu tek merkezli retrospektif kesitsel çalışmada, pnömoni tanısı ile hastaneye yatırlan hastalarda pnömoni gelişiminde önemli risk faktörleri incelenmiş; komplikasyon gelişimi ve prognoz üzerine etkilerinin değerlendirilmiştir. Küçük yaş, prematüre doğum öyküsü, düşük doğum ağıllığı, anne sütü almamak, eksik aşılanma ve malnütrisyonun çocuklarda pnömoni nedenli hastaneye yatışlar için önemli risk faktörleri olduğu gösterilmiştir. Yoğun bakım ünitesine yatış gereksinimini, yoğun bakım ünitesinde yatış süresini ve komplikasyon gelişimini etkileyen faktörler olarak ise ek nörolojik ve genetik hastalıkların varlığı ve düşük oksijen saturasyonu olarak belirlenmiştir.

Araştırmamızda hastaların ortanca yaşı 14 ay olup, 2 yaş altı hasta oranı \%65.4 ve 5 yaş altı hasta oranı \%81 olarak saptanmıştır. Literatürde yapılan çalışmalarda pnömoni sıklğı̆ın en fazla 0-2 yaş grubunda olduğu gösterilmiştir. Pnömoni 
Tablo III: Hastalarda saptanan mikroorganizmalar.

\begin{tabular}{|c|c|c|c|c|}
\hline \multirow[b]{2}{*}{ Değişkenler } & \multirow{2}{*}{$\begin{array}{c}\text { Tüm } \\
\text { popülasyon } \\
\mathrm{n}=289\end{array}$} & \multicolumn{2}{|c|}{ Uyruk } & \multirow[b]{2}{*}{$\mathbf{p}$} \\
\hline & & $\begin{array}{c}\text { Türkiye } \\
\mathrm{n}=258\end{array}$ & $\begin{array}{c}\text { Suriye } \\
n=31\end{array}$ & \\
\hline \multicolumn{5}{|l|}{ Üreyen Mikroorganizma } \\
\hline Yok & 263(91.0) & 234(90.7) & 29(93.5) & \\
\hline Var & 26(9.0) & 24(9.3) & $2(6.5)$ & 0.848 \\
\hline Achromabacter species (kan kültürü) & $1(0.3)$ & $1(0.4)$ & - & 0.999 \\
\hline Candida albicans(kan kültürü) & $2(0.7)$ & $2(0.8)$ & - & 0.999 \\
\hline Enterococcus (kan kültürü) & $1(0.3)$ & - & $1(3.2)$ & 0.204 \\
\hline Pseudomonas (ETA) & $2(0.7)$ & $2(0.8)$ & - & 0.999 \\
\hline RSV (Solunum yolu viral paneli) & $1(0.3)$ & $1(0.4)$ & - & 0.999 \\
\hline Human metapneumovirus (SWVP) & $1(0.3)$ & $1(0.4)$ & - & 0.999 \\
\hline Influenza (SYVP) & $1(0.3)$ & $1(0.4)$ & - & 0.999 \\
\hline Klebsiella pneumoniae (kan kültürü) & $3(1.0)$ & $2(0.8)$ & 1(3.2) & 0.738 \\
\hline Koagülaz negatif stafilokok (kan kültürü) & $7(2.4)$ & $7(2.7)$ & - & 0.756 \\
\hline Pseudomonas aeruginosa (kan kültürü) & $4(1.4)$ & $1(1.2)$ & 1(3.2) & 0.908 \\
\hline Coronavirüs (SWP) & $1(0.3)$ & $1(0.4)$ & - & 0.999 \\
\hline Rhinovirüs (SWP) & $2(0.7)$ & $2(0.8)$ & - & 0.999 \\
\hline Staphylococcus aureus (balgam) & $1(0.3)$ & $1(0.4)$ & - & 0.999 \\
\hline Staphylococcus haemolyticus (kan kültürü) & $1(0.3)$ & $1(0.4)$ & - & 0.999 \\
\hline Staphylococcus epidermidis (kan kültürü) & $1(0.3)$ & $1(0.4)$ & - & 0.999 \\
\hline
\end{tabular}

küçük çocuklarda çok daha sık görülmektedir. Özellikle 0-1 yaș arası çocuklarda öksürük refleksleri zayıftır ve solunum kaslarını iyi kullanamadıkları için solunum yolu sekresyonlarını temizlemeleri yetersizdir; bu nedenle en riskli grup olarak karșımıza çıkmaktadır. 1-5 yaș arasındaki çocuklar ise bağıșıklık sistemi gelișimini tamamlamamıs olmaları nedeniyle ikinci riskli grubu oluşturmaktadırlar (3-5).

Araștırmamızda pnömoni tanısı ile hastaneye yatırılan hastaların \%19.7'sinin prematüre doğum öyküsü olduğu, \%23.9'unun düșük doğum ağırlığı ile doğduğu ve \%31.5'inin yenidoğan döneminde anne sütü almadığı belirlenmiștir. Ayrıca, prematüre doğum öyküsü olanlarda mikroorganizma üreme oranı daha yüksek saptanmıştır. Prematüre doğum öyküsü olan bebeklerde enfeksiyon ve sepsis riskinin daha yüksek olmasının, bu hasta grubunda sekonder mikroorganizma üremesinde hastalığın hem prognozuna hem de komplikasyonlarına olumsuz etki sağlayacağı yapılan çalışmalarda gösterilmiştir (6). Prematüre doğumu tetikleyen faktörler ve özellikle fetal enfeksiyonlar da bu bebeklerde pulmoner enfeksiyonlara ve sepsise yatkınlık sağlayan bir durum yaratır. Bununla birlikte mekanik ventilasyon intiyacı olan prematüre bebeklerin immatür akciğer yapısı mekaniğine sekonder artmış pulmoner infeksiyon riski de eklenir. Prematüre doğan bebeklerde pnömoni gibi solunumsal problemler term bebeklere göre daha sık görülmekte ve bunların mekanizması immatür akciğer yapısı, fetal akciğer sıvısının klirensindeki bozukluklar, sürfaktanın miktarının yetersizliği ve yapısal bozukluğu ile ilişkili olduğu bilinmektedir. Ayrıca prematüre doğum öyküsü olan çocuklarda demir, çinko, bakır ve diğer nütrient depoları azdır ve bu çocukların çoğunda düşük doğum ağıllı̆ı gözlenir. Düşük doğum ağırlığı olan bebeklerde yenidoğan döneminde anne sütü alım süresinde azalma ve yetersiz beslenme sık görülür. Ayrıca düșük doğum ağırlığı öyküsü olan çocuklar akciğer fonksiyonlarının azalması ve immün yetmezlik nedeniyle pnömoni için risk grubunda bulunmaktadır (7). Bununla birlikte anne sütünün pnömoniden koruyuculuğu olduğu ve yenidoğan döneminde anne sütü alamayan çocuklarda alanlara göre 17 kat daha fazla pnömoni nedeniyle hastaneye yatış olduğu bildirilmiştir (8).

Araștırmamızda hastaların \%82'sine așı yapıldığı belirlenmiștir. Dünya Sağlık Örgütü verilerine göre 2016 yllında ülkemizde çocuklarda așılanma oranı \%90'nın üzerindedir (9). Çalıșmamıza dahil edilen hastalarda ise kesin olarak așılanmıș olanların oranı Türkiye ortalamasına (\%94) göre daha düșük bulunmuștur (10). Aslında Türkiye vatandaşı hastalarda aşlama oranı \%87 iken Suriye uyruklu çocuk hastalarda așllanma oranı $\% 42$ 'dir ve bu durum genel insidansta azalma ile kendini göstermiștir. Araştırmamızda 5 yaş üstündeki hastaların hastaneye yatış süresinin daha uzun olduğu ve komplikasyon gelișiminin daha fazla olduğu görülmüștür. Șubat 2010 ylında T.C. Sağllk Bakanlığı tarafından ruhsatlandırlan ve 2011 ylında 7 valanlı konjuge pnömokok așısı (KPA7) așısından 13 valanlı konjuge pnömokok așısı (KPA13) așısına geçilmesinin bu durumda etkili olduğunu düșünmekteyiz. KPA7 ile tam olarak așılanmıș çocuklarda bu aşıdaki serotiplere karşı korunma sağlanmaktadır ancak KPA13 içinde bulunan ilave altı serotip ile enfeksiyon geçirme riski devam etmektedir.

Araștırmamızda, hastaların \%27'sinde ebeveynleri arasında akrabalık saptanmıștı; ayrıca ebeveynlerinde akraba evliliği olan çocukların oranı mikroorganizma varlığı gösterilen grupta daha yüksektir.

Çalışmamızdaki hastaların \%37'sinde ek tanı mevcut olup, çoğunlukla nörolojik hastalıklar (\%16.6), solunum yolu hastalıkları (\%7.6), kardiyovasküler hastallklar (\%6.6) ve genetik hastalıklar (\%6.2) belirlenmiștir. Araștırmamızda ek nörolojik hastalık varlığı hastanede yatıș süresinin uzaması, mikroorganizma üremesi ve 
Tablo IV: Hastalarda antibiyotik kullanımı.

\begin{tabular}{|c|c|c|c|c|}
\hline \multirow[b]{2}{*}{ Antibiyotik } & \multirow{2}{*}{$\begin{array}{l}\text { Tüm popülasyon } \\
n=289\end{array}$} & \multicolumn{2}{|c|}{ Uyruk } & \multirow[b]{2}{*}{$\mathbf{p}$} \\
\hline & & $\begin{array}{c}\text { Türkiye } \\
\mathrm{n}=\mathbf{2 5 8}\end{array}$ & $\begin{array}{c}\text { Suriye } \\
n=31\end{array}$ & \\
\hline Yok & $8(2.8)$ & $8(3.1)$ & - & 0.999 \\
\hline SAM & $146(50.5)$ & 127(49.2) & 19(61.3) & 0.255 \\
\hline Klaritromisin & 70(24.2) & 61(23.6) & $9(29.0)$ & 0.510 \\
\hline Seftriakson & $58(20.1)$ & $52(20.2)$ & $6(19.4)$ & 0.999 \\
\hline Oseltamivir & $38(13.1)$ & 35(13.6) & $3(9.7)$ & 0.746 \\
\hline Sefotaksim & $37(12.8)$ & $33(12.8)$ & $4(12.9)$ & 0.999 \\
\hline Teikoplanin & $27(9.3)$ & $27(10.5)$ & - & 0.118 \\
\hline Vankomisin & $15(5.2)$ & $15(5.8)$ & - & 0.342 \\
\hline Piperacillin/Tazobactam & $14(4.8)$ & $14(5.4)$ & - & 0.375 \\
\hline Meropenem & $11(3.8)$ & $9(3.5)$ & $2(6.5)$ & 0.751 \\
\hline Amikasin & $9(3.1)$ & $8(3.1)$ & $1(3.2)$ & 0.999 \\
\hline Sefepim & $9(3.1)$ & $8(3.1)$ & $1(3.2)$ & 0.999 \\
\hline Flukonazol & $6(2.1)$ & $6(2.3)$ & - & 0.848 \\
\hline Klindamisin & $6(2.1)$ & $6(2.3)$ & - & 0.848 \\
\hline Siprofloksasin & $4(1.4)$ & $4(1.6)$ & - & 0.999 \\
\hline Kaspofungin & $3(1.0)$ & $2(0.8)$ & $1(3.2)$ & 0.738 \\
\hline Asiklovir & $3(1.0)$ & $3(1.2)$ & - & 0.999 \\
\hline Ampisilin & $3(1.0)$ & $3(1.2)$ & - & 0.999 \\
\hline Linezolid & $2(0.7)$ & $2(0.8)$ & - & 0.999 \\
\hline Kolistin & $2(0.7)$ & $2(0.8)$ & - & 0.999 \\
\hline Seftazidim & $2(0.7)$ & $2(0.8)$ & - & 0.999 \\
\hline Metronidazol & $2(0.7)$ & $2(0.8)$ & - & 0.999 \\
\hline Sulbaktam/Sefoperazon & $1(0.3)$ & $1(0.4)$ & - & 0.999 \\
\hline Azitromisin & $1(0.3)$ & $1(0.4)$ & - & 0.999 \\
\hline Ornidazol & $1(0.3)$ & $1(0.4)$ & - & 0.999 \\
\hline Ertapenem & $1(0.3)$ & $1(0.4)$ & - & 0.999 \\
\hline Gentamisin & $1(0.3)$ & $1(0.4)$ & - & 0.999 \\
\hline Linkomisin & $1(0.3)$ & $1(0.4)$ & - & 0.999 \\
\hline
\end{tabular}

YBÜ yatışı ile anlamıı ilişki göstermiştir. Çocuklarda ek nörolojik hastalıkların bulunması pnömoni seyrini, sonucunu ve olası komplikasyonlarını etkileyecek önemli bir risk faktörüdür (1112). Bu nedenle, nörolojik hastalıkları olan çocuklarda tıbbi bakımın ilk aşamasında, pnömoni riskini önleyici programların oluşturulmasına önem verilmelidir.

Araştırmamızda ev içi hava kirliliğinin en önemli sebeplerinden biri olan pasif sigara maruziyeti \%26.6 olarak saptanmıștır. Daha önce yapılan çalışmalarda da bu durumun pnömoni için risk faktörü olduğu gösterilmiştir (13-14). Pasif sigara içimi ve pnömoniye bağlı olarak oksidatif stres faktörlerinin artması, antioksidan savunmayı zayıflatarak oksidatif hasarı artırabilir; çeşitli akciğer hastalıklarının etyopatogenezinde önemli rol oynayabilir (15). Pasif sigara içimi, pnömoni için hem hazırlayıcı hem de ilerletici bir risk faktörü olarak işlev görebilir. Pnömoni için diğer bir risk faktörü de evde yaşayan kişi sayısının fazla olmasıdır ki bu durum bulaştıııclık açısından önemli bir risk faktörüdür (16-17). Araştırmamızda geniş aile oranı \%14.9, 2 ve üzeri kardeş sayısı olan hastaların oranı \% 43 olarak belirlenmekle birlikte ailesinde solunum yolu enfeksiyonu öyküsü olanların oranı \%20.8 olarak saptanmıştır. Araştırmamızda Suriye uyruklu hastalarda Türk uyruklu hastalara kıyasla kalabalık aile ortamına sahip olmaları toplum genelinde artan pnömoni insidansına katkı sağladığı düşünülmektedir.

Çalışmamızda hastalar en sık öksürük (\%86.5) ve ateş (\%60) semptomları ile hastaneye başvurmuşlardır. Fizik muayene bulgularında ise en sık takipne (\%68.9), retraksiyon (\%60.9), ral-ronküs (\%48.1) bulunmuştur. Gelişmekte olan ülkelerde DSÖ tarafından pnömoni tanımı ateş ve takipne bulguları olarak gösterilmiştir (18). Yapılan çalışmalarda hipoksemiye ait artmış mortalite ve morbidite riskini göstermede takipne en önemli göstergelerden biridir (19). Takipnenin pnömoniyi göstermedeki duyarlılı̆ı \%50-81, özgüllüğü \%54-70 civarındadır $(20,21)$.

Araştırmamızda hastaların \%10'unda malnütrisyon saptanmıştır. Hastaneye yatışta, mikroorganizma üremesinde ve YBÜ'nde yatışta malnütrisyon ile anlamlı ilişki gösterilmiştir. Malnütrisyon özellikle hücresel immünitede baskilanmaya yol açar. 
Tablo V: Hastane yatış süresine göre YBÜ yatışı ve izlemi.

\begin{tabular}{|c|c|c|c|c|}
\hline \multirow[b]{2}{*}{ Değişkenler } & \multicolumn{3}{|c|}{ Hastane Yatış Süresi } & \multirow[b]{2}{*}{ p } \\
\hline & $\begin{array}{l}1 \text { hafta } \\
n=171\end{array}$ & $\begin{array}{c}2 \text { hafta } \\
n=67\end{array}$ & $\begin{array}{c}>2 \text { hafta } \\
n=51\end{array}$ & \\
\hline $\begin{array}{l}\text { YBÜ yatış } \\
\text { Yok } \\
\text { Var } \\
\text { YBÜ yatış süresi }\end{array}$ & $\begin{array}{c}150(87.7) \\
21(12.3) \\
3(1-6)\end{array}$ & $\begin{array}{r}42(62.7) \\
25(37.3) \\
3(1-14)\end{array}$ & $\begin{array}{c}23(45.1) \\
28(54.9) \\
11(1-115)\end{array}$ & $\begin{array}{l}<0.001^{*} \\
<0.001^{*}\end{array}$ \\
\hline $\begin{array}{l}\text { Pnömoni komplikasyonu } \\
\text { Yok } \\
\text { Var } \\
\text { Plevral effüzyon } \\
\text { Atelaktezi } \\
\text { Pnömotoraks } \\
\text { Ampiyem } \\
\text { Pnömotasel } \\
\text { Sepsis }\end{array}$ & $\begin{array}{c}163(95.3) \\
8(4.7) \\
5(2.9) \\
3(1.8) \\
0 \\
0 \\
0 \\
0\end{array}$ & $\begin{array}{c}63(94.0) \\
4(6.0) \\
3(4.5) \\
2(3.0) \\
0 \\
0 \\
0 \\
0\end{array}$ & $\begin{array}{c}25(49.0) \\
26(51.0) \\
19(37.3) \\
3(5.9) \\
4(7.8) \\
2(3.9) \\
1(2.0) \\
1(2.0)\end{array}$ & $\begin{array}{c}<0.001^{*} \\
<0.001^{*} \\
0.200 \\
0.001^{*} \\
0.028^{*} \\
0.176 \\
0.176\end{array}$ \\
\hline $\begin{array}{l}\text { Solunum desteği } \\
\text { Maske ile } \mathrm{O}_{2} \\
\text { Yüksek akımı } \mathrm{O}_{2} \\
\text { NCPAP } \\
\text { Mekanik ventilasyon }\end{array}$ & $\begin{array}{c}139(81.3) \\
15(8.8) \\
5(2.9) \\
4(2.3)\end{array}$ & $\begin{array}{c}48(71.6) \\
14(20.9) \\
2(3.0) \\
11(16.4)\end{array}$ & $\begin{array}{r}30(58.8) \\
11(21.6) \\
8(15.7) \\
17(33.3)\end{array}$ & $\begin{array}{r}0.004^{*} \\
0.010^{*} \\
0.003^{*} \\
<0.001^{*}\end{array}$ \\
\hline $\begin{array}{l}\text { Tedavi sonrası } \\
\text { Taburcu oldu } \\
\text { Exitus }\end{array}$ & $\begin{array}{c}170(99.4) \\
1(0.6)\end{array}$ & $\begin{array}{c}65(97.0) \\
2(3.0)\end{array}$ & $\begin{array}{c}48(94.1) \\
3(5.9)\end{array}$ & $0.035^{\star}$ \\
\hline
\end{tabular}

$\mathrm{Bu}$ nedenle enfeksiyonlar daha ağır geçer. Malnütrisyon öyküsü olan çocuklarda protein yapımı ve yıkımı, hücresel immunite, fagosit fonksiyonu, kompleman sistemi, sekretuar immunoglobulin A antikor düzeyi ve sitokin yapımı azalma gösterir, immun yanıt azaldığından ağır enfeksiyonlar daha sIk görülür. Solunum yolunda sekretuar lgA konsantrasyonu azalır $(22,23)$. Solunum kaslarındaki zaylflık da eklenince solunum yolu enfeksiyonlarındaki artışa bağı olarak pnömoni insidansında artış gözlenir. Malnütrisyon pnömoni ciddiyetini ve mortaliteyi de arttırmaktadır (24-26). Yapılan çalışmalar ışığında malnütrisyon varlığının, pnömoninin hem gelişmesinde hem de kötü prognozunda ciddi bir risk faktörü olduğu gözlenmektedir.

Araștırmamızda hastaların \%25.6'sının YBÜ'nde yattığı belirlenmiștir. Araștırmamızda YBÜ'de yatıș ile ilișkili bulunan olası risk faktörleri, hastaların özgeçmișlerinden elde edilen bilgilere göre postnatal dönemde küvözde kalma, mekanik vantilatörde kalma, malnütrisyon, nörolojik ve genetik hastallk varlığı ve $\mathrm{O}_{2}$ saturasyonunun düşüklüğü olarak saptanmıştır. Ayrıca YBÜ'nde yatan hastaların \%24.3'ünde mikroorganizma üremesi olmuştur. Cinsiyet, yaş, doğum haftası, doğum şekli ve prenatal özellikler açııından YBÜ yatışı ile anlamlı ilişki saptanmamış olmakla birlikte YBÜ'de yatan hastaların \%59.4'ü 2 yaş altındadır. Tayvan'da yapılan bir çalışmada pnömoni tanısı ile izlenen YBÜ'nde yatan çocukların \%48.4'ü 2 yaş altı olduğu belirtilmiştir (27). Araştırmamızda artan yaşın hastaneye yatış süresinde ve komplikasyon gelişmesinde olası bir risk faktörü olduğu belirlenmiștir.

Araştırmamızda YBÜ'nde yatan hastalarda ortanca $\mathrm{SpO}_{2}$ düzeyi \%90 (60-100)'dır. Oksijen saturasyonunun \%92'nin altında olması YBÜ'nde yatış için önemli endikasyonlardan biridir ve bu durumdaki hastalara düzenli oksijen tedavisi verilmesi gerekir (28). Alt solunum yolu enfeksiyonlarında hipoksemi uzamış hastane yatıșı, yoğun bakım ve ventilasyon gereksinimi ile ilişkilidir (28). Yapılan bir prospektif kohort çalışmasında hipoksemisi olan çocukların hastanede yatış sürelerinin daha uzun ve mortalite oranlarının daha fazla olduğu belirtilmiștir (19). Çalışmamızda da YBÜ'nde yatan hastalarda düşük $\mathrm{SpO}_{2}$ düzeyi ile birlikte oksijen tedavisine olan intiyaç anlamlı olarak daha fazla bulunmuştur. Ayrıca araştırmamızda $\mathrm{SpO}_{2}$ değerleri azaldıkça hastanede yatış süresinin uzadığı gösterilmiștir. Oksijen tedavisi intiyacı YBÜ'ne yatış gereksiniminin erken bir göstergesidir.

Hastaların laboratuvar bulguları incelendiğinde iki haftadan uzun süre hastanede yatanlarda, mikroorganizma üremesi olanlarda, komplikasyon gelișenlerde hastaneye bașvuruları sırasında ölçülen CRP düzeyi daha yüksek bulunmuștur. Bu bulgu araştırmamızda CRP düzeylerinin literatürle uyumlu olarak hastanın kötü prognozunda önemli bir gösterge olabileceğini desteklemektedir (29). Chalmers ve ark.(30) tarafindan yapılan araştırmada hastaların giriş CRP değerinin 100 mg/l altında olmasının mortaliteyi, mekanik ventilasyon ihtiyacını ve/ veya inotrop desteğini ve komplike pnömoni riskini azalttığı saptanmıştır.

Araştırmamızda akciğer grafilerinde hastaların \%85.8'inde pnömonik infiltrasyon, \%3.5'inde lober konsolidasyon ve $\% 0.3$ 'ünde atelaktazi saptanmıştır. Ayrıca pnömonik infiltrasyon ve atelaktazi birlikteliği olan hasta oranı \%2.1'dir. Bununla birlikte plevral effüzyonun eșlik ettiği pnömonik infiltrasyon oranı 
\%2.8 ve lober konsolidasyon oranı \%1.1 olarak saptanmıştır. Akciğer grafisi normal saptanan hasta oranı ise \%4.5 olarak belirlenmiştir. Akciğer grafisinde alveolar infiltrasyon, pnömokok pnömonisi gibi tipik bakteriyel pnömoninin bir göstergesi olarak değerlendirilebilir; intertisyel infiltrasyon ise viral veya atipik bakteriyel enfeksiyonun bir göstergesi olabilir (31). Diğer yandan viral etkeni belirlemede antijen saptama ve PCR metodlarının, bakteriyel etkeni belirlemede immün kompleks metodlarının kullanıldığı çalışmalarda bu görüş doğrulanamamıştır (31).

Çalışmamızda hastaneye yatırlan tüm pnömonili hastalardan kan kültürü alınmıştır. Ayrıca plevral effüzyon örneklemesi, gerekli ise solunum yolu sekresyonlarından örnekleme (balgam kültürü, solunum yolu viral paneli gibi) yapılmıştır. Buna rağmen mikroorganizma saptama oranı düşük bulunmuştur (\%9). Saptanan mikroorganizmalar açısından en sık gözlenen (\%2.4) Koagülaz negatif stafilokok (KNS) (n:7) ve (\%1.4) Pseudomonas aeruginosa (n:4) olarak belirlendi. Bunlar haricinde 3 vakada (\%1) Klebsiella pneumoniae, 2'şer vakada Pseudomonas (ETA), (\%0.7) Candida albicans, (\%0.7) RSV ve Rhinovirüs, 1'er vakada (\%0.3) Achromobacter species, Enterococcus, Human metapneumovirus, Influenza, Coronavirüs, Staphylococcus aureus, Staphylococcus haemolyticus, Staphylococcus epidermidis saptanmıştır. Yapılan çalışmalarda, hastanede yatışları sırasında pnömonili çocukların kan kültürlerinin sadece \%3-5'inde pozitiftir $(32,33)$. Bizim çalışmamızda hastanede yatışları süresince hastalardan alınan kan kültürlerinin \%5'inde mikroorganizma gösterildi. 2013'te yapılan bir çalısmaya göre ise, hastaneye yatırlarak tedavi edilen pnömoni tanılı çocuklarda kan kültüründe üreme \%7; 2017'deki bir çalsşmada ise \%2.5 olarak tespit edilmiştir $(34,35)$. Lee ve Harper tarafından 2-36 aylık çocuklarda yapılan çalışma ile Alpern ve ark. (36) tarafindan 2-24 aylık ateşli çocuklarda yapılan çalışmalarda gizli bakteriyeminin en önemli nedeni olan Streptococcus pneumoniae'nın kan kültüründen en sık izole edilen bakteri olduğunu ve Haemophilus influenzae tip b'nin hiç izole edilmediğini bildirmişlerdir. Bizim çalışmamızda da hiçbir hastadan Haemophilus influenzae tip b izole edilmedi.

Çalışmamızda hastaların büyük çoğunluğuna ampirik olarak antibiyoterapi başlanmış, hastaların \%56.7'sında monoterapi, \%40.5'inde birden fazla antibiyotik ile kombinasyon tedavisi uygulanmıştır. En çok kullanılan antibiyotikler \%50.5'inde SAM (Sulbaktam/Ampisilin), \%24.2'sinde klaritromisin, \%20.1'ine seftriakson verildiği saptanmıştır. 8 hastada (\%2.8) viral pnömoni düşünüldüğü için antibiyotik tedavisi düzenlenmemiştir. Mikroorganizma üremesi olan hastalar yoğun bakım ünitesinde yatan komplike pnömonilerdir ve bu üremelerin hastane kaynaklı olduğu düşünülmüştür. Mikroorganizma üreyenlerde flukonazol, seftazidim, meropenem, siprofloksasin, kaspofungin, teikoplanin, amikasin kullanım oranı yüksek saptanmışıı. Solunum yolu viral panelinden elde edilen sonuçlar daha anlamlıdır, diğerleri takipte gelişen üremelerdir. Bu hastalarda bakteriyel PCR çalıştıııması anlamlı sonuç sağlayabilir fakat maliyeti yükselteceği için tercih edilmemektedir. Hastanemizde ampirik antibiyotik tedavisi sonrası 283 hasta (\%97.9) tedavisi tamamlanarak sağlıklı bir şekilde taburcu olmuştur; bu durum da ampirik antibiyotik tedavisinin başarısını göstermektedir.

Araştırmamızda 2 hastada ampiyem saptandı, bu hastaların 1'inde Pseudomonas aeruginosa ürediği ve piperacilin/ tazobactam, linezolid, vankomisin tedavisi aldığı belirlendi. Diğer ampiyem gelişen hastada ise mikroorganizma üremediği ve başka komplikasyonu olmadığı, seftriakson, klindamisin ve teikoplanin tedavisi aldığı saptandı. Çocukluk çağında plevral efüzyon, en sık bakteriyel pnömoniler sırasında görülür. Pnömoniye plevral efüzyon eşlik etmesi ve sonrasında ampiyem gelişmesi prognozu kötüleştirerek hastanede kalış süresinin uzamasına ve morbiditenin artmasına neden olmaktadır (37). Genel olarak çocuklarda plevral efüzyonlara yaklaşım erişkinlere göre daha konservatiftir (38). Çocukların yaş gruplarına göre antibiyotik tedavisi en sık görülen pnömoni patojenlerine yönelik olmalı ve infeksiyonun hastane ve toplum kökenli olmasına göre düzenlenmeli ve tüm hastalara mutlaka intravenöz antibiyotikler verilmelidir.

Araştırmamızın önemli kısıtlılıkları, hastaların epikrizlerindeki eksik bilgilere ulaşmanın mümkün olmaması, bu nedenle kayıtlarda olmayan risk faktörlerinin saptanamamasıdır. Ayrıca yabancı uyruklu hastaların yarısının bilgilerine dil problemi nedeniyle ulaşılamamıştır.

Sonuç olarak, bütün dünyada çocuklarda önemli bir mortalite ve morbidite nedeni olan pnömonide erken tanı ve tedavi çok önemlidir. Küçük yaş, prematüre doğum öyküsü, düşük doğum ağıllı̆ı, anne sütü almamak, eksik aşılanma ve malnütrisyon çocuklarda pnömoni nedenli hastaneye yatışlar için önemli risk faktörleridir. Yoğun bakım ünitesine yatış gereksinimini, yoğun bakım ünitesinde yatış süresini ve komplikasyon gelișimini etkileyen faktörler olarak ise ek nörolojik ve genetik hastalıkların varlığı ve düşük oksijen saturasyonu olarak belirlenmiştir. Ulusal aşılama programının eksiksiz uygulanması, malnutrisyonun önlenmesi, kalabalık yaşam koşullarının düzeltilmesi ve ev içi ve dışı hava kirleticilerinin özellikle de sigara maruziyetinin önlenmesi hastalı̆ı önlemede, ağır pnömoni nedeni ile hastaneye yatışın önlenmesinde önemlidir. Hastalığın seyrini ve prognozunu, komplikasyonlarını ve hastanın hastanede yatış süresini etkileyen olası risk faktörlerinin belirlenip önlenmesi çocukluk çağında pnömonilerin morbiditesini azaltacaktır.

\section{KAYNAKLAR}

1. Ebeledike C, Ahmad T. Pediatric Pneumonia. StatPearls. Treasure Island (FL); 2019.

2. WHO. Pneumonia 2017. Erişim adresi: https://www.who.int/ news-room/fact-sheets/detail/pneumonia.

3. Kosai H, Tamaki R, Saito M, Tohma K, Alday PP, Tan AG, et al. Incidence and Risk Factors of Childhood Pneumonia-Like Episodes in Biliran Island, Philippines--A Community-Based Study. PLoS One 2015;10:e0125009. 
4. Jain S, Williams DJ, Arnold SR, Ampofo K, Bramley AM, Reed $\mathrm{C}$, et al. Community-acquired pneumonia requiring hospitalization among U.S. children. N Engl J Med 2015;372:835-45.

5. Banstola A, Banstola A. The epidemiology of hospitalization for pneumonia in children under five in the rural western region of Nepal: a descriptive study. PLoS One 2013;8:e71311.

6. Colin AA, McEvoy C, Castile RG. Respiratory morbidity and lung function in preterm infants of 32 to 36 weeks' gestational age. Pediatrics 2010;126:115-28.

7. Hassan MaK, Al-Sadoon I. Risk factors for severe pneumonia in children in Basrah. Tropical doctor 2001;31:139-41.

8. César JA, Victora CG, Barros FC, I S Santos, J A Flores. Impact of breast feeding on admission for pneumonia during postneonatal period in Brazil: nested case-control study. BMJ 1999;318:131620.

9. Unicef. Erişim adresi: https://data.unicef.org//wp-content/uploads/ country_profiles/Turkey/Immunization-coverage-estimates-2018_ tur.pdf.

10. Eskiocak M, Marangoz B. TTB: Türkiye'de Bağışıklama Hizmetlerinin Durumu. Erişim adresi: www.ttb.org.tr.

11. Zubarenko O, Kopiyka G, Kravchenko T, Koval L, Gurienko K. Peculiarities of Community-Acquired Pneumonia in Children with Neurological Pathology. Georgian Med News 2017:95-9.

12. Millman AJ, Finelli L, Bramley AM, Peacock G, Williams DJ, Arnold $\mathrm{SR}$, et al. Community-Acquired Pneumonia Hospitalization among Children with Neurologic Disorders. J Pediatr 2016;173:188-95 e4.

13. Le Roux DM, Myer L, Nicol MP, Zar HJ. Incidence and severity of childhood pneumonia in the first year of life in a South African birth cohort: the Drakenstein Child Health Study. Lancet Glob Health 2015;3:e95-e103.

14. Moustaki M, Nicolaidou P, Stefos E, V Vlachou, P Patsouri, A Fretzayas. Is there an association between wheezing and pneumonia? Allergol Immunopathol (Madr) 2010;38:4-7.

15. Okşak N, Karakılçık AZ. Pasif sigara içimine maruz kalan pnömonili çocuklarda antioksidan enzim aktiviteleri, kapiller kan oksijen satürasyonu ve laktik asit değerleri. Genel Tıp Dergisi 2018;28:1-5.

16. Da Fonseca Lima EJ, Mello MJG, Lopes MIL, Serra GHC, Lima MA, Lopes MIL, et al. Risk factors for community-acquired pneumonia in children under five years of age in the post-pneumococcal conjugate vaccine era in Brazil: a case control study. BMC pediatrics 2016;16:157.

17. Wonodi CB, Deloria-Knoll M, Feikin DR, Deluca AN, Driscoll AJ, Moisi JC, et al. Evaluation of risk factors for severe pneumonia in children: the Pneumonia Etiology Research for Child Health study. Clin Infect Dis 2012;54:S124-S31.

18. WHO. Pneumonia 2017. Erişim adresi: https://www.who.int/ news-room/fact-sheets/detail/pneumonia

19. Usen S, Weber M, Mulholland K, Jaffar S, Oparaugo A, Omosigho $\mathrm{C}$, et al. Clinical predictors of hypoxaemia in Gambian children with acute lower respiratory tract infection: prospective cohort study. BMJ 1999;318:86-91.

20. Berman S, Simoes E, Lanata C. Respiratory rate and pneumonia in infancy. Archives of disease in childhood 1991;66:81.

21. Taylor JA, Del Beccaro M, Done S, Winters W. Establishing clinically relevant standards for tachypnea in febrile children younger than 2 years. Arch Pediatr Adolesc Med 1995;149:283-7.

22. Rodriguez L, Cervantes E, Ortiz R. Malnutrition and gastrointestinal and respiratory infections in children: a public health problem. Int $J$ Environ Res Public Health 2011;8:1174-205.
23. Tomkins A, Watson F. Malnutrition and infection: a review. United Nations Administrative Committee on Coordination/Sub Committee on Nutrition 1989:136pp.

24. Hooli S, Colbourn T, Lufesi N, Costello A, Nambiar B, Thammasitboon S, et al. Correction: Predicting Hospitalised Paediatric Pneumonia Mortality Risk: An External Validation of RISC and mRISC, and Local Tool Development (RISC-Malawi) from Malawi. PLoS One 2018;13:e0193557.

25. Hooli S, Colbourn T, Lufesi N, Costello A, Nambiar B, Thammasitboon S, et al. Predicting Hospitalised Paediatric Pneumonia Mortality Risk: An External Validation of RISC and mRISC, and Local Tool Development (RISC-Malawi) from Malawi. PLoS One 2016;11:e0168126.

26. Ngari MM, Fegan G, Mwangome MK, Ngama MJ, Mturi N, Scott JAG, et al. Mortality after Inpatient Treatment for Severe Pneumonia in Children: a Cohort Study. Paediatr Perinat Epidemiol 2017;31:233-42.

27. Hsu CL, Lee YS, Chen CJ, Lee ML, Yang CF, Soong WJ, et al. A population-based analysis of children with pneumonia among intensive care units in Taiwan. J Microbiol Immunol Infect 2015;48:153-9.

28. Majumdar SR, Eurich DT, Gamble JM, Senthilselvan S, Marrie TJ. Oxygen saturations less than 92\% are associated with major adverse events in outpatients with pneumonia: a population-based cohort study. Clin Infect Dis 2011;52:325-31.

29. Reny JL, Vuagnat A, Ract C, Benoit MO, Safar M, Fagon JY. Diagnosis and follow-up of infections in intensive care patients: value of C-reactive protein compared with other clinical and biological variables. Crit Care Med 2002;30:529-35.

30. Chalmers JD, Singanayagam A, Hill AT. C-reactive protein is an independent predictor of severity in community-acquired pneumonia. Am J Med 2008;121:219-25.

31. Korppi M. Community-acquired pneumonia in children. Pediatric Drugs 2003;5:821-32.

32. Shaheen SO, Sterne JA, Tucker JS, Florey CD. Birth weight, childhood lower respiratory tract infection, and adult lung function. Thorax 1998;53:549-53.

33. Cevey-Macherel M, Galetto-Lacour A, Gervaix A, Siegrist CA, Bille $J$, Ninet BB, et al. Etiology of community-acquired pneumonia in hospitalized children based on WHO clinical guidelines. Eur J Pediatr 2009;168:1429-36.

34. Myers AL, Hall M, Williams DJ, Auger K, Tieder JS, Statile A, et al. Prevalence of bacteremia in hospitalized pediatric patients with community-acquired pneumonia. Pediatr Infect Dis J 2013;32:736-40.

35. Neuman MI, Hall M, Lipsett SC, Hersh AL, Williams DJ, Gerber JS, et al. Utility of blood culture among children hospitalized with community-acquired pneumonia. Pediatrics 2017;140:e20171013.

36. Alpern ER, Alessandrini EA, Bell LM, Shaw KN, McGowan KL. Occult bacteremia from a pediatric emergency department: current prevalence, time to detection, and outcome. Pediatrics 2000;106:505-11.

37. Mocelin HT, Fischer GB. Epidemiology, presentation and treatment of pleural effusion. Paediatr Respir Rev 2002;3:292-7.

38. Givan DC, Eigen H. Common pleural effusions in children. Clin Chest Med 1998;19:363-71. 